\title{
NEW ENTRANTS IN AGRICULTURE - THE CASE OF YOUNG IMMIGRANT FARMERS IN SWEDEN
}

Ann Grubbström, Sofie Joosse ${ }^{1}$

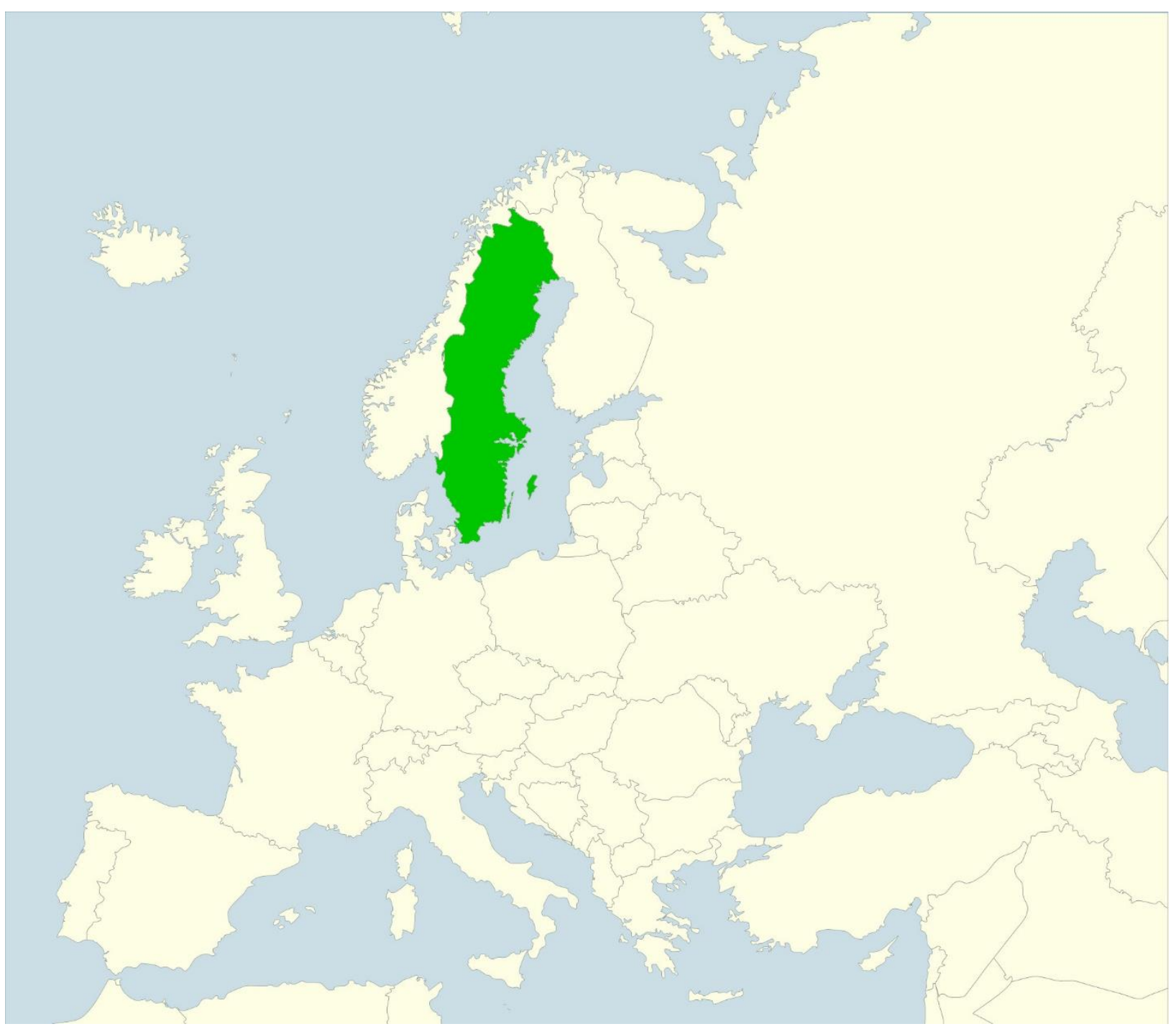

${ }^{1}$ Ass. Prof. Ann Grubbström, email: ann.grubbstrom@slu.se, Sofie Joosse, PhD., sofie.joosse@slu.se, Department of Urban and Rural Development, Swedish University of Agricultural Sciences Uppsala, Sweden 


\begin{abstract}
The opportunities available to start up a successful farm business structure the future of European farming. As fewer farm daughters and sons are projected to take over the family farm, there is increasing policy and academic interest in new entrants and the challenges they meet when they start their farm. This study focuses on new entrants that immigrate to Sweden. This group can be considered an extreme case of new entrants, as key resources (land, local networks, family labour support and farm specific knowledge are usually lacking for these farmers). Based on interviews with immigrant farmers in the Mälardalen region, we present the different ways they get access to economic, cultural and social capital. These insights are valuable for policy aimed at helping immigrant farmers starting up.
\end{abstract}

Keywords: Young farmers, new entrants, immigrant farmers, capital, trust

\title{
Highlights:
}

- Immigrant farmers develop innovative holding arrangements.

- Lack of key resources as local knowledge makes immigrant farmers vulnerable.

- Building networks and combining knowledge in a new way are important strategies.

- To build trust is a key aspect to get access to different forms of capital.

\section{Introduction}

A prospected decrease in the numbers of both current farmers and future farmers poses challenges for farming businesses across Europe. One out of three European farmers is over 65 and is likely to retire within the coming ten years (EU, 2016). At the same time, it is projected that fewer farmers' sons and daughters want to, or can, continue the family farm. This "young farmer problem" (Zagata \& Sutherland, 2015, Hamilton et al. 2015; Eistrup et al. 2019) has led to increased interest from researchers, policy makers and farmers in possibilities for non-family farm transfer (Burton \& Fischer, 2015, Joosse \& Grubbström, 2017, Carolan, 2018, Valliant et al., 2019). However, non-family farm transfer is no easy solution, for a variety of reasons. First, farms have become more capital-intensive, and new entrants ${ }^{2}$ rarely have access to sufficient financial assets. Indeed, finding land at a reasonable price requires family or at least (local) connections (Grubbström \& Eriksson, 2018) and networks (Meuleners, 2013). Family farm successors can often buy out siblings for a price below market value, but surging land prices (Kauffman, 2013) makes farm transfer to new entrants an expensive procedure (EP, 2017). Second, farm-specific and local knowledge have been highlighted as key ingredients for successful farm establishment. Such knowledge is an integral part of being born and raised on a farm (Kennedy, 1991). As such, this knowledge is often informal (Šūmane et al., 2018) and difficult to access for outsiders, such as new entrants usually are. Third, family farm successors typically still rely on help and support from family for labour and knowledge. On many farms the parents are often helping the successor when he/she is taking over the farm. Such extensive farm specific help is seldom available to the new entrant.

Both policy and academia increasingly acknowledge challenges for starting farmers (both young farmers taking over the family farm and new entrants) and reports and studies are generating new insights. EU reports highlight policy measures that enable sharing practical knowledge and support during succession (EP, 2017), and the need for advisories that are adapted to young farmers' specific situation (EU, 2015). Research articles have critiqued the focus of policy

\footnotetext{
${ }^{2}$ We follow the broader definition of new entrant as proposed in a discussion paper for the EU commission: "A natural person, group of people or legal entity who have within the past five years established a new agricultural holding or farming business in their own name(s). The natural person, group of people or legal entity should be actively farming (i.e. producing agricultural products for sale) and be either establishing a new agricultural holding or returning to a family-held holding after a minimum of 10 years of off-farm employment" (EU, 2015: 5).
} 
measures on economic factors, such as financing, production and business management (Valliant et al., 2019), and argue they should be accompanied by measures that target young farmers' sometimes challenging social and psychological situation (May et al., 2019). Such measures could help young farmers to better integrate and find their ways in the farming community, and help deal with pessimism in a pressed sector (May et al., 2019). Within this group of farmers deserving special attention, new entrants are highlighted specifically, and scholars stress they should be assessed separately both in research and policy since their situation differs from family successors (Hamilton et al., 2015). The general tenor of all these publications together is that young farmers deserve and need special attention especially for the social aspects of establishment of a farm business, and that more research is needed to address these challenges (Meuleners, 2013; May et al., 2019). In light of the above, this article aims to contribute to an academic and practical understanding of the possibilities and constraints for new entrants to start a farm business. We focus on new solutions for holding arrangements, as called for by Zagata \& Sutherland (2015). Our study zooms in on the experiences of young immigrant farmers in Swedish agriculture. Young immigrant farmers can be considered an extreme case of new entrants. The typical feature of family inheritance; decreased need of financial capital to access land, local networks, family support and years-long experience and knowledge of the family farm, are usually lacking completely for these farmers from elsewhere. As such, the focus on immigrant farmers is justified as it can all the more clearly highlight the enablers and constraints of establishing a successful farm business for new entrants. The paper is guided by the following research questions:

1. What kind of holding arrangements do young immigrant farmers develop?

2. What challenges and opportunities do they meet in these different arrangements?

3. How do they, in and through these arrangements, compensate for the lack of local networks and knowledge and family support?

In section 2, we describe Swedish agriculture as a changing sector with fewer and larger farms, attracting immigrant farmers. In section 3 we use the conceptual lens of economic, social and cultural capital and translate the research problem and research questions in these terms. In section 4, we present our methodology, case selection and informants. Section 5 forms the analysis where we discuss examples of how immigrant farmers have gained access to land through different holding arrangements, and how these arrangements enable or constrain the farmers to compensate for lacking capital. In section 6, we deepen our analysis of the challenges that the young immigrant farmers face and in what way the lack of local networks and knowledge and family support make this specific group of new entrants vulnerable. In section 7 , we elaborate on how the immigrant farmers compensate for the lack of these key resources in farming.

\section{Background: fewer and larger farms, and immigrating farmers in Sweden}

The Swedish agricultural landscape is changing drastically. The number of Swedish farms decreased by $50 \%$ between 1970 and 2016 (Swedish Board of Agriculture, 2017), and by $11.4 \%$ between 2010 and 2016 (Swedish Board of Agriculture, 2018). In the years to come, we can expect more changes. The percentage of farm holders over 64 years of age increased steadily from $18.6 \%$ in 2005 to $30 \%$ in 2016 (Table 1). As these farm holders are likely to retire within the coming 10 years, we expect a further acceleration in the decrease in farm holdings and an increase in the number of farm transfers initiated in the coming years. Only $4.6 \%$ of Swedish farmers are younger than 34 and $15.4 \%$ are younger than 44 (Table 1 ). Important to note here is that these official numbers do not always represent the reality on the farm: in our research, we have met several young farmers that were in charge of the business even though the official farm holder was one of the parents. This kind of successive farm transfer indicates that the actual number of young farmers in business are hidden in the statistics. Therefore, while the agricultural statistics demonstrate clear trends in generational change, we cannot on the basis of these figures exactly predict the number of prospective farmers, the number of people that are in the process of, or aiming to take over. 
Tab 1. Age distribution of farm holders in Sweden 2010-2016 (based on Swedish Board of Agriculture, 2018: 107).

\begin{tabular}{|l|l|l|l|l|l|l|l|l|l|l|}
\hline & $<\mathbf{2 5}$ & $\mathbf{2 5 - 3 4}$ & $\mathbf{3 5 - 4 4}$ & $\mathbf{4 5 - 4 9}$ & $\mathbf{5 0 - 5 4}$ & $\mathbf{5 5 - 5 9}$ & $\mathbf{6 0 - 6 4}$ & $\mathbf{3} \mathbf{6 4}$ & N.a. & Total \\
\hline $\mathbf{2 0 1 6}$ & $0.5 \%$ & $4.1 \%$ & $10.8 \%$ & $8.8 \%$ & $\mathbf{1 1 . 8 \%}$ & $\mathbf{1 2 . 7 \%}$ & $\mathbf{1 2 . 7 \%}$ & $30.4 \%$ & $8.4 \%$ & 62937 \\
\hline $\mathbf{2 0 1 3}$ & $0.3 \%$ & $3.5 \%$ & $11.4 \%$ & $10.4 \%$ & $11.9 \%$ & $13.1 \%$ & $13.0 \%$ & $28.6 \%$ & $8.3 \%$ & 67146 \\
\hline $\mathbf{2 0 1 0}$ & $0.3 \%$ & $3.8 \%$ & $13.3 \%$ & $11.0 \%$ & $12.8 \%$ & $12.9 \%$ & $13.7 \%$ & $\mathbf{2 4 . 9} \%$ & $8.3 \%$ & 71091 \\
\hline
\end{tabular}

The change in the agricultural landscape consists not only in the number of farms but also in the size of the farms and the character of farming. The average size of a farm has almost doubled since 1970 to 40ha (Swedish Board of Agriculture, 2017). This scale enlargement continues into the present time, as the number of farms over 200ha continues to increase (Table 2). Interestingly, in recent years, very small-scale farms (under 2 ha) are also on the increase, evidencing new farm strategies and farm diversification. Because of the average scale enlargement, in combination with the development of agricultural technology leading to productivity gains, the decrease in the number of farms resulted in only a barely detectable decrease in the level of production of Swedish farms (Swedish Board of Agriculture, 2017).

Tab 2. Percentage of holdings by size group (ha) (Swedish Board of Agriculture, 2018:37).

\begin{tabular}{|c|c|c|c|c|c|c|c|c|c|c|c|c|c|}
\hline & $<2$ & $2-5$ & $5-10$ & $10-20$ & $20-30$ & $30-50$ & $\begin{array}{l}50- \\
100\end{array}$ & $\begin{array}{l}100- \\
200\end{array}$ & $\begin{array}{l}200- \\
300\end{array}$ & $\begin{array}{l}300- \\
400\end{array}$ & $\begin{array}{l}400- \\
500\end{array}$ & $500>$ & Total \\
\hline 2016 & $6.6 \%$ & $14.7 \%$ & $21.4 \%$ & $18.1 \%$ & $8.6 \%$ & $9.3 \%$ & $10.8 \%$ & $6.7 \%$ & $2.1 \%$ & $0.7 \%$ & $0.3 \%$ & $0.5 \%$ & 62937 \\
\hline 2013 & $5.8 \%$ & $15.1 \%$ & $20.6 \%$ & $18.5 \%$ & $8.9 \%$ & $10.0 \%$ & $10.9 \%$ & $6.6 \%$ & $1.8 \%$ & $0.6 \%$ & $0.3 \%$ & $0.3 \%$ & 67146 \\
\hline 2010 & $5.3 \%$ & $16.3 \%$ & $19.6 \%$ & $18.3 \%$ & $9.2 \%$ & $10.5 \%$ & $11.5 \%$ & $6.3 \%$ & $1.6 \%$ & $0.5 \%$ & $0.2 \%$ & $0.3 \%$ & 71091 \\
\hline
\end{tabular}

This study focuses on new entrants, and specifically on young immigrant farmers. In Sweden, one of 50 agricultural entrepreneurs has a foreign background. Most of them come from the Nordic countries or other EU countries. Agricultural entrepreneurs who have a foreign background are generally younger, with a higher proportion of women, compared to the entrepreneurs with a Swedish background (Swedish Board of Agriculture, 2014).

Our interviewees mainly come from The Netherlands. Sweden is attractive for Dutch new entrants because of lower land prices and lower competition for land (Woods, 2014). Access to land is identified as the main barrier for new entrants to enter agriculture in Europe (EP, 2017). In Sweden, agricultural land is under pressure in the more populated regions but easy to get by in more remote areas where land prices are also relatively low (Swedish Board of Agriculture 2019). Besides these economic advantages, Sweden is an attractive alternative because of its social and cultural similarities with The Netherlands.

On average, immigrant farmers in Sweden have larger farms, compared to Swedish farmers, with over 100 milking cows. It is also common that they have plans for further enlargements (Swedish Board of Agriculture 2007:17). In this way, immigrant farmers impact the structure and character of Swedish rural areas when they maintain farming in the area by taking over family farms (Compare Eimermann, 2015), and by the increased farm size. The changing landscape with fewer farms in turn also impacts the new entrants, as well as established farmers, for example as it leads to fewer colleagues closeby to collaborate with.

\section{Social, economic and cultural capital for new entrants}

In western Europe, farm ownership and management have primarily been passed on within the family (Errington and Lobley, 2002). In 2010, 92 per cent of the Swedish farms were family farms (EU, 2014), meaning that Swedish agriculture is much shaped by family farm practices. 
Therefore, previous research has foremost studied family farm holding arrangements. However, with current trends, there is a need for more insight in non-family farm holding arrangements. This paper focuses on young immigrant farmers to gain more insight in non-family farm holding arrangements, and we analyse how such arrangements may compensate for key resources that often are a natural part of family succession (Pérez et al. 2020) but lacking in non-family farm establishment.

To analyse this, we use Bourdieu's conception of economic, social and cultural capital. Economic capital is "immediately and directly convertible into money and may be institutionalized in the form of property rights" (Bourdieu 1986: 242). In our study, we refer to economic capital as economic resources to get access to material property such as farm land, farm buildings, and farm machines.

Social capital is "the sum of the resources, actual or virtual, that accrue to an individual or a group by virtue of possessing a durable network of more or less institutionalized relationships of mutual acquaintance and recognition" (Bourdieu \& Wacquant, 1992: 119). In our study, we are interested in networks of social connections. Networks are a crucial source of information and support for farmers (Mailfert, 2007), and can support the farmer to identify opportunities for farm development, but also more indirectly, such a network or community can contribute to feelings of optimism and hope in relation to farming and one's farm business (Maclean et al. 2014). To have contact with farming colleagues is important to facilitate knowledge exchange, practical collaboration and opportunities for networking (Ngo \& Brklacich's, 2014; Borisov et al. 2019). As such, collaborations, learning opportunities and feelings of belonging are crucially dependent on the nature of the relationships between the involved individuals. Social capital tends to lead to more social capital "as existing relationships are reinforced through ongoing interactions". (Sutherland \& Burton 2011: 249) This is an advantage for the family successors who may naturally take over the social capital accrued by their parents, in terms of local networks, collaboration and support while new entrants and especially immigrants will have to start building local social capital from the bottom-up.

Cultural capital refers to knowledge and values invested by the family (Bourdieu, 1986). In the case of the immigrant farmers, we discuss cultural capital in farming as knowledge and values collected through contacts and experiences with other farms and farmers. Lobley (2010) discusses local knowledge as knowledge about the specific farm and its environment. Such knowledge could, for example, concern which seeds are suitable to grow in different fields of a specific farm. Farm-specific knowledge is based on experience of being and working on the farm: over time the farmer builds up a sophisticated understanding of the livestock, the soils and how to work with them. Local knowledge could be, for example, knowledge of who in the local area could help out with machines, or where the farmers usually meet. Ashkenazy et al. (2017) emphasise that local knowledge is important for agricultural resilience. However, in the case of immigrant farmers, this kind of local knowledge is unknown, and they need to find ways to get access to it from local people or farmers. Experiences from other farms are drawn upon when taking decisions and finding solutions for your own farm (Inwood \& Sharp, 2012; Darnhofer et al. 2016). Maclean et al. (2014) see "knowledge partnerships" where the farmers exchange knowledge as a part of their collaboration as crucial for an individual's ability to adapt in connection to change. They also describe the process whereby experiences from different levels - local, national and international - are adapted to the local level.

Symbolic capital is the symbolic representation of the other forms of capital (Bourdieu, 1986). Siisiainen (2003) writes about symbolic capital as a capital of recognition: "The roots or sources of symbolic capital can be almost anywhere, its central criterion is that actors perceive and recognize its existence". The symbolic capital is discussed here in the terms of trust. Trust is a form of recognition and a valuable resource when trying to get access to the other forms of capital. In a study of young farmers' social capital in Greece, Koutsou et al. (2014) shows that trust is an essential ingredient for success. However, building trust takes time, and the immigrant farmers need to start from the beginning with building trust within local and national networks.

Key resources, here conceptually translated in different forms of capital, have a crucial effect on the establishment of the farm. At first glance, family successors seem to have easier access to 
all forms of capital, whereas for new entrants and even more so for the young immigrant farmers, all these forms of capital seem more difficult to get by. In the next sections, we will investigate how young immigrants still manage to establish a farm, while seemingly lacking these key ingredients of successful farm start-up.

\section{Method}

This article draws on a combination of empirical material from two projects, namely Looking for farmers. Young farmers' strategies in a changing sector and Swedish farms closures. An opportunity for farmers from other countries? In these projects, we performed qualitative interview studies with young farmers in the Mälardalen region in Sweden.

Mälardalen is attractive for farmers, it has generally good agricultural land and is an active farming region, with relatively many farms. It is home to two large cities, Stockholm and Uppsala, which means that farmers have larger markets close by, and a relatively high supply of service connected to agriculture such as repair and construction companies.

Interviews were used to find out more about different farm holding arrangements and the possibilities and challenges that the interviewees saw with these arrangements and their farms. The interviews were conducted during 2012-2017. In total, we interviewed 26 young farmers aged 23-45 years representing 18 different farms. Nine farms were family farms and four of them were (or were in the process of) being transferred to a daughter. As mentioned earlier, some of these farms were still in the possession of the parents. In this way, the economic responsibility could be delayed, and it was also a way for the young farmer to try things out. Nine farms were bought or leased. All interviews are used as a reference but in this paper, we zoom in on immigrant farmers, and the five individual interviews with young immigrant farmers were selected for deeper analysis (Table 3). We found the situation for the immigrant farmers especially interesting since we were struck by their creative ways of solving challenges of getting access to land, local knowledge and support. Even though we focus on these five interviews, we use the whole set of interviews to mirror the situation for the immigrant farmers against the situation described by the family farmers. The immigrant farmers that are in focus for the analysis are referred to with fictive names. They were all full-time farmers and the majority were dependent on milk production. One farmer, Jan, was interviewed twice: first in 2012 when he was leasing, and then again in 2017 as a buyer (Table 3).

Tab 3. Interviewed young immigrant farmers. Source: own elaboration

\begin{tabular}{|l|l|l|}
\hline Name in the paper (year for interview) & Country of origin & Land arrangement \\
\hline Willem and Celine (2012) & Belgium & Leasehold \\
\hline Jan (2012) & The Netherlands & Leasehold \\
\hline Danielle and Jan (2017) & The Netherlands & Bought \\
\hline Max (2012) & The Netherlands & Bought \\
\hline Karen and Peter (2017) & The Netherlands & Bought \\
\hline
\end{tabular}

We got in contact with the interviewees via the federation of Swedish farmers (LRF). Additional interviewees were found through recommendations from the farmers we met. The interviews took place at the farm and lasted around one to two hours. Being at the farm often involved a tour around the farm which increased our understanding of the situation. For example, farmers could point out where the former farmer lived, new solutions for milking or plans for new buildings. In three of the interviews with immigrant farmers, both partners in the farming couple participated (Table 3). Our intention was to meet both men and women farmers but a majority of the persons on the list from LRF were men, similar to the gender division in agriculture as a whole in Sweden. However, on many farms it was not just a man, but rather a man and a woman in a relationship that were farming together. Since both of them were engaged in the business it was natural to do the interview with both, even though this was not the plan beforehand. This turned out to be an advantage since each partner could tell his/her own stories and at the same time complement the other's stories. 
Interviews were recorded and thereafter transcribed verbatim. The first analysis was made after the interviews when we discussed our first reflections and made notes. In a second step, the transcript was coded in themes related to: 1) land access in relation to landholding arrangements and the opportunities and challenges they experienced within these arrangements 2) networks; 3) knowledge, and 4) support. In a third step, they were related to the different forms of capital to make a deeper analysis of how it was possible to get access to key resources, and in what way they are important for immigrant farmers. We also analysed how capital could be transferred, for example, that social capital as networks and important contacts gave access to economic capital. This also helped us to identify the symbolic capital trust as a representation of the other forms of capital. Trust was identified as crucial for getting access to the other forms of capital. In the next section, we give examples of different holding arrangements and how the immigrant farmers within these arrangements find ways to get access to different forms of capital.

\section{Immigrant farmers' solutions of holding arrangements}

The interviewed immigrant farmers in this study were unable to buy a farm in their home country, as they lacked the financial capital for the relatively expensive farm prices. Often, immigrants had heard about Sweden from someone in their network who had already moved to Sweden. So me had started as agricultural workers in Sweden. They describe the farming business in The Netherlands as more efficient; for example, help with a broken-machine is usually available locally without the need to travel long distances, and increased competition leads to better service. Nevertheless, Sweden was attractive as land prices are much lower and it is much easier to lease additional land. Since access to land is one of the most important preconditions for establishing a viable farm (EP, 2014) these favourable conditions for leasing additional land are crucial for farmers who want to enlarge their business. In summary, these farmers feel that Sweden can provide competitive advantages for running a relatively large business (compare Woods, 2014).

\subsection{Immigrant farmers purchasing land}

One strategy to get access to land, is of course to purchase it. Here we look at the experiences of three immigrant farmers from The Netherlands who have purchased a farm in Sweden.

\section{Access to land}

The interviewees had no opportunity to start farming in The Netherlands. Peter grew up on a farm but his parents in their 50s were not ready for generational succession and considered him too young (26 at that time) to take over. He had experience from several countries and had friends who had moved to Sweden. Peter and his wife Karen took a vacation in Sweden to get to know the country and met a man who had worked on an attractive farm that was for sale. They made contact and decided to buy the farm. The interviewed immigrant farmers identify personal contacts as key for their successful farm purchase. Peter and Karen had a personal contact in the bank, which they think made it possible to get a loan.

Jan and Danielle, who went from a leasing contract to buying their own farm, feel much calmer as landowners, instead of leasers. Previously, they felt worried that their leasing contract would be terminated due to non-payment, but now they can ask the bank for some amortization-free months if they are in economic trouble. However, glad they are with their new position as owners, they emphasise that the first years of leasing were a necessary stepping-stone for the eventual farm purchase. During the lease years, they established a local network, built trust within that network and with their closest contacts and, importantly, with the bank. All of these contacts helped them to ensure a successful deal. Our respondents all told us that they had a clear vision of how they wanted to run the farm. All of them also stressed that the first years were especially challenging when they made many changes towards their vision, but also general problems that farmers encounter. For instance, Peter and Karen had many problems with cow udder health and had to slaughter half of the milking herd. Peter describes their first time:

The first year, it went quite well, better than expected, even though the costs were high... The last years they (former owners) had done no maintenance, no repairing or fixing...everything was, 
yes, finished... So the first three years were tough. It was just spending money. But it was just to keep on working.

It was a challenge to at the same time, keep the costs as low as possible, improve the herd's health, and also experiment and move towards their vision. While this task seems daunting, Peter recounted that they told themselves: you should not be afraid for anything!

In the narratives with all these respondents the idea of 'streamlining the business' stood central. One strategy that Jan and Danielle used for this streamlining was to become more self-sufficient, cultivate their own fodder, and use their own manure. Interviewees also told us they believed that in order to survive in farming, they would need to enlarge the business in the future. Jan and Danielle think that they could have around 250 milking cows within ten years. However, this also means that they need more land since they want to grow their own fodder.

\section{Finding knowledge and support}

Our interviewees have experience from different farms and different countries they have worked in and visited. It widens your view a little... it might be easier to build your own views and not to be so affected by traditions. In discussing this, they compare their own situation in relation to those who have inherited a farm. Generational succession within the family could result in creative solutions but also strengthen path dependency and a desire to follow family traditions (Šumane et al., 2018). The interviewees emphasize the latter and think that those who inherit a farm might continue in the same way and use the same network as their fathers instead of calling someone else and see what happens. They emphasize the importance of meeting other farmers to realize that they can look at the problem in a different way. They describe how they have picked up different ideas from different countries and farms and selected those that suit their business. This also means that they feel flexible and ready to take tough decisions. They think that farmers in Sweden are generally a little bit more cautious.

To move in from another country means that you need to access knowledge about the Swedish system as a whole, as well as local knowledge and specific knowledge about the farm you have bought. International contacts, existing contacts in their home country, as well as local contacts in the new location make the immigrant farmer's knowledge sources rich. To talk to and have contact with others is a strategy for handling uncertainty and stressful situations that occur. This is in line with Herman et al. (2018) study of Finnish organic farmers who received support, practical information, exchange and encouragement from a social network of biodynamic farmers. Interviewees describe the challenge of learning about the Swedish system, such as, for example, different rules and regulations. Research highlights the importance of the local farmer's knowledge since it "contains an intimate understanding of the particular set of local cultural and natural resources" (Šūmane et al. 2018, pp. 233). What happens when this knowledge is missing, which is the case for immigrant farmers? Interviewees describe how they access farm-specific knowledge (for example, soil conditions or how successful the cultivation of a specific crop has been) by asking the former farmer or to retain a workforce that already knows the animals and the farm. Peter and Danielle had an agreement to work together with the former owner at the farm for one month after they had bought the farm, just to make sure that they could ask questions and get some introduction to how things worked.

In summary, to have access to economic capital they have built trust with personal contacts at the bank. The cultural capital in the form of farm-specific as well as local knowledge has been built up through their large network. This, in combination with a high level of generic farming knowledge gained from different international experiences, gives them the opportunity to combine their different kinds of knowledge. However, as Maclean et al. (2014) point out, the ability to adapt these different sources of knowledge to their specific farm is vital and with no doubt a challenge without their own farm specific and local knowledge. The social capital is crucial for support and decision making. However, immigrant farmers must invest time and energy to develop trust in their partnerships to get access to this knowledge and support. Something that family farmers might have built up over the years. In addition, a family relationship can, besides knowledge transfer, involve parents working long hours at old age to help their children. An engagement and support that is hard to expect from a non-family relationship. 


\subsection{Leasing land from an investor}

One interviewed young farmer from The Netherlands and a couple from Belgium, contacted investors who were interested in buying land, but had no intention of farming themselves. The investors look at the land not only as an investment but also as something that can fulfill their dreams and meet their ideological values: to live in a farmhouse in the countryside, to build a summerhouse, to be able to hunt in the forest, or to be able to contribute to organic production. One of the interviewees even searched for a suitable farm together with an investor. The selling farmer is also pleased with this solution since the arrangement will lead to active farming and retention of the animals on the property. As one of the young farmers, Jan, said: The old farmer thought it was a great solution since he really wanted the cows to remain on the farm, because the cows were his life's work. This arrangement is an attractive solution for everyone involved and the farm lives on. For the leasers it might be a "stepping stone" to being able to buy their own farm in the future. The arrangement makes it possible to start up a business with animals and machines without needing to personally have access to a large amount of economic capital (Figure 1).

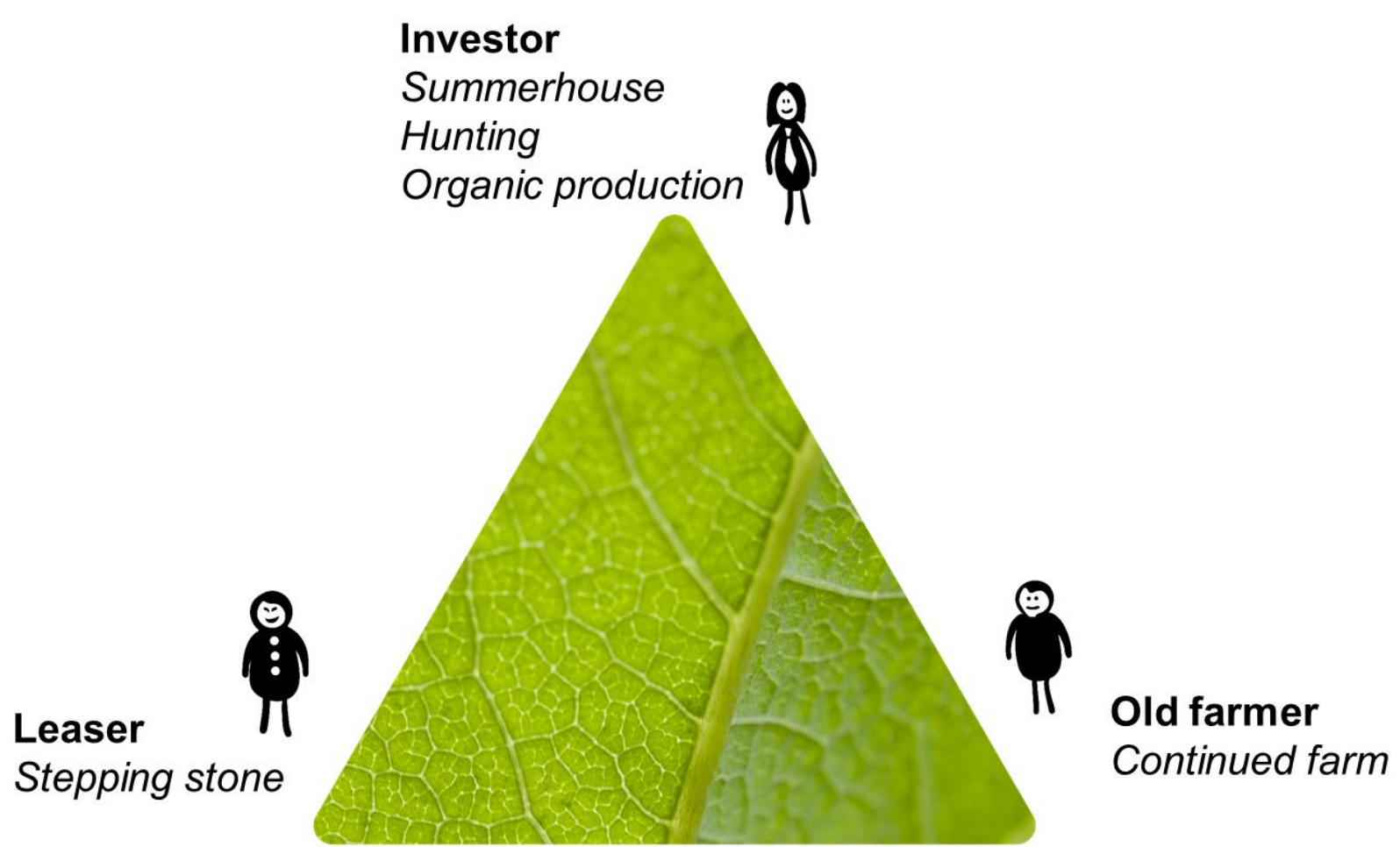

Fig 1. The benefits for all involved in the "investor leasehold". Source: Ann Grubbström

Willem and Celine are about to start an organic farm, their dream farm, and to build a new cowshed that will be paid for by the landowner. They want to have cows with horns, which needs more space than ordinary milk cows. They have spent a lot of time completing the drawings: We have travelled abroad and looked at farms and we have drawn and drawn and thought through and called several farmers that we know... We have picked out the best from all the farms that we have been to... and then we want to make our own thing of everything. In this way, they have used the experiences of others when they have found their own solution. Willem and Celine are not interested in expanding right now, they want to test their ideas about producing milk on a smaller scale. In this case, the ideological ideas and thoughts unite the landowner and the leaser in a common plan for the business.

This example shows how social capital in the form of networks can support the immigrant leaseholder in different ways. This network both involves contact with an investor to get access to land, contact with a former farmer as well as other farmers for advice and inspiration to design and develop the farm business. It also shows how cultural capital evolves by combining different knowledge from the old farmer, the investor and the young farmer to develop a successful 
business. The old farmer can be of both practical and emotional support when leasing land. However, the downside with such a relationship could be that the young farmer holds back new ideas and changes out of consideration for the old farmer's feelings (Joosse and Grubbström 2017, Grubbström \& Eriksson 2018). In the investor leasehold described here, there is no practical support from the investor; instead, the investor acts more as a discussion partner. A challenge is to maintain a good relation with the investor since they could have conflicting visions of how the farm business should proceed. This relationship could also be related to power where the owner has much more power in this relation and the leaser needs to deal with this when bringing forward suggestions and future plans.

It could be easier to make changes and introduce new ideas to a landowner that has no history on the farm and no traditions to consider. But if the old farmer still lives on the land, or nearby, considerations towards the old farmer could still be involved in an investor leasehold. Our interviews show examples of how former farmers have intervened too much and made the leasers' work more difficult. The leaser then needs to balance their own interest and ambitions with respect to the old farmers' feelings for the farm and opinions on how things should be done.

\section{Immigrant farmers' vulnerable situation}

The interviewed farmers have creative ways to enter and manage the farming business. However, the young farmers are well aware of the risks involved. The interviewees identify four major challenges that could eventually lead to financial breakdown for their business. First, a lower price for their products, such as milk, meat and grain. Second, the weather, which is an uncertain factor impossible to control; if the weather is too hot, too wet or too cold several years in a row, that could mean a big challenge for the business. Third, a crisis in the farmer's private life. This third challenge is of another character, since it is possible to influence but also more permanent than fluctuating prices and weather. The hard workload with responsibility of 24 hours a day and the economic pressures are hard for a partner to handle. As Jan says: If I am 25000 kroner minus on my account for the farm, it is hard to be happy. That will affect my mood and make private relations harder. Danielle recalls when the milk price was at its bottom and they had just invested in a new farm, which she remembers as a trial without it's like. Economic problems are the worst threat to the relationship and they realised that they had to stop discussing them at bedtime.

Danielle: "As much as I work, and then you sit at the wrong time, and eat something and so damn, we have to pay the bills. And then you pick up the computer and then you start paying bills and, as it was last autumn so, well, here we have another pile of bills and, we have 15 bills left and the money is gone...it's not very nice to go to bed together then. It is not, because both of us feel bad about it and it is hard on the relationship, it is very hard and it is very unhealthy."

Now they decided to talk about it before lunch and in that way have time to melt it during the day and can handle it in a better way. Fourth, the challenge that the workload will be too heavy. The workload must be sustainable and that is not the case for many of the interviewees right now. Jan emphasises how continuing with the same workload could be a threat to their health and the farm business: When you get too tired, you cannot think clear and then you cannot handle a business anymore. It could, for example, be dangerous to drive the machines when you have not slept or worked too many hours in a row. There is a limit for the workload that should not be exceeded. Peter, does all the milking himself. That takes six hours a day and after that, he feeds the cows. It happens that he gets up at four in the morning and works 20 hours a day. A standard week is about 120 hours. The goal is that in the future, they will work a normal workday and be able to take vacations.

The third and fourth challenges are related, since a heavy workload can cause relationship problems. Sexsmith's (2019) study of dairy farmers in New York shows that farmers oppose the tradition in farming of always working, since it dramatically affects their social life. They desire a more modern lifestyle than earlier generations, with vacations and time for family activities and a social life. Our interviewees also express concerns about how the long working days influence their relationships. Max claims that he almost lost his life while working too much. At the age of 27 , he ended up at the hospital with a heart attack and, in addition, his work situation led to 
a divorce. Jan also thinks that his first relationship crashed because of the heavy workload and a harsh economic situation. He also thinks that one of the most important threats to the farm business in the future is if he and his current partner Danielle break up. Danielle explains how they complement each other and that the whole business depends on their combined knowledge. That they indeed need to run the business together. This importance of having a partner to share the burden with is also stressed by new farmers in Canada (Ngo \& Brklacich, 2014) where important aspects of a successful farming were financial, operational and emotional support from a partner. Jan says that the current long working hours are not sound. In order to be able to continue as farmers, they need to work less. Just because I am a farmer, I shouldn't have to work twice as much as an ordinary person. There is no reason. In fact, I don't accept it. This shows that interviewees are very aware that they work too much and that the extreme workload is a risk to both their health and their business. The point we want to stress is that new entrants and specifically immigrant farmers' situation with a lack of social and cultural capital in the form of local networks and knowledge and in addition lack of family work support are in a vulnerable position. They have a potentially higher risk than family farmers to end up in a situation where they work too much which also, according to them, could trigger a crisis in their private life. Hence, the challenges are related since they could trigger a chain effect with economic problems, heavier workload and relational problems. Social capital in the form of support from a partner seems crucial for the immigrant farmers and in the next paragraph, we deepen our reasoning about other ways to get access to social capital in the form of cooperation and support to counteract the vulnerable situation.

\section{The importance of social capital in the form of cooperation and support}

Regardless of land arrangement, cooperation and contact with other farmers is crucial to stay positive and to find solutions to problems. Examples of cooperation with other farmer colleagues are sharing animals, machines and producing milk and cheese. Cooperation is important for direct financial reasons as handling change, such as price fluctuation in a constructive way but also for learning and support. Danielle and Jan think that their network is extremely important. Their cooperation with other dairy farmers makes it possible to ask questions and discuss problems and possible solutions. They also give each other tips about companies to cooperate with and machines that work well. As Jan said:

If you get a problem with something, for example, high cells for the cows. You might ask your colleagues what should I do? Where should I start to look? Everyone comes with their little part... I also had problems and I solved it like this- yes, I will try that.

He also emphasizes that it feels easier when you have a problem and hear that someone else faces the same difficulties. The network is vital to be able to start cooperation and to create a knowledge partnership where the participants contribute with their knowledge and experience for mutual learning. Cooperation also encourages the participants to search for new knowledge to continue the development of their farms. Max thinks that cooperation makes farming more fun: you don't just sit at your farm, you meet people and develop new things together. Hence, cooperation might lead to new ideas and in that way be positive for the business. The interviewees highlights that cooperation also means that you have someone with whom to discuss, for example, the right day to harvest. The character of networks has been affected by the reduction in number, and the increase in size, of farms. Contact needs to happen now over larger distances and farmers tell us they have contacts in the whole of Sweden to check fodder prices and grain prices. Farmers highlight that the lack of farming neighbors is a negative effect of the rationalization but that smartphones could be used to talk to other farmers instead of meeting them. For these farmers social media seems to be more and more important for the feeling of social support from others.

Cooperation is in many cases described as something positive but can also, not surprisingly, be a source of conflict. Peter, for example, has an agreement with the former owner that he can use the machine hall in exchange for Peter using his machines. It turned out that the former farmer always needs help and Peter is tired of providing unpaid work. This illustrates the complicated relationship between needs and dependency. A farmer might need cooperation but if it does not 
work out well, the conflict can be complicated to resolve, especially if there is a dependency involved such as when a landowner or even a former landowner lives close to the farm. In these cases, there is a high social cost involved in discussing the issue and a deterioration of the relationship is risked. It is easier to break a relationship with someone who is not family which is disadvantageous for non-family successors. To conclude; Social capital in the form of cooperation is important for many young farmers but it seems that it might have a more decisive role for immigrant farmers. Cooperation contributes with a combination of financial benefits and social support. It seems to be one way to compensate for the support and knowledge transfer that family successors often get from their parents.

\section{Concluding discussion}

This study analyses two non-family types of farm transfer, involving purchasing and leasing. In the analyses, we have discussed immigrant farmers' challenges and opportunities that these arrangements bring with them. Moreover, we discussed how the immigrant farmers compensate for the lack of key resources in farming such as access to land, local networks and knowledge as well as family support. Here we discuss these findings through different forms of capital: economic, symbolic, cultural and social capital. Our contribution is to show how these different forms of capital are important for immigrant farmers and how they find ways to get access to them. We also show how they are interlinked.

\section{Economic capital: the importance of symbolic, cultural and social capital to get access to land}

Farmers usually get access to land through the family while immigrant farmers need to buy land on the open market or lease land. Cultural and social capital can be converted into economic capital (Bourdieu, 1986). This is illustrated in this study when immigrant farmers build cultural and social capital to get access to economic capital to buy or lease land. However, to be able to build cultural and social capital, they need recognition in the form of trust (see also, Koutsou et al.,2014). Trust is also important to access economic capital. The immigrant farmers who bought their farm had to build trust with the old farmer, the bank and the branch as a whole. This is also the case for the young farmers leasing land from an investor. They need to build trust both with the investor and sometimes the old farmer if that farmer still lives in the area. The investor needs to know that the leaser is competent and hardworking and will fulfill their common goal to run a successful business. Trust is an important aspect also within the family business but our study shows that trust is even more crucial for the immigrant farmer that lacks key resources as family support and already established networks. When building trust, aspects of power relations are important to highlight. Solutions that we have provided examples of here, where the leaser is recruited outside the family, make the young farmer's ability to deal with power relations highly relevant since a good relation to the owner is a requirement for continued leasehold and investments. Immigrant farmers are in a more exposed position compared to family successors in such agreements since a family relation is more forgiving and can usually stand conflicts and disagreements better than a non-family relation.

\section{Cultural capital: Combining knowledge in a new way}

Cultural capital in the form of knowledge is important for how new entrants can develop the business. This study gives new perspectives on this since the immigrant farmers lack the specific farm and local knowledge that has been identified in earlier research as crucial (Ashkenazy et al. 2017). Instead, they use their wide experience from other farms and countries to challenge the local knowledge and ways of being a farmer in an innovative way. This does not mean that they do not value specific farm- or local knowledge. They use their new local network to learn what they think is necessary: for example, an understanding of local norms, and views about how to be a goodfarmer in Sweden (Sutherland \& Burton, 2011). Moreover, a close contact with the former farmer or neighbors can help immigrant farmers to access important knowledge about the specific farm, which is combined with their generic agricultural knowledge and international experience. 


\section{Social capital: Networks for social support and cooperation}

The young farmers emphasize the value of access to social capital in the form of networks that give possibility for cooperation. As identified by earlier research (Mailfert, 2007; Herman et al. 2018; Maclean et al. 2014), this study also shows that networks with other farmers are crucial for information and support. Networks make it possible to discuss problems and different solutions and in that way get support. The ability to find and manage these networks seems to be crucial for a successful business. The role of social media appears increasingly important and we welcome future research into this way of communication and its perceived usefulness for farmers. The immigrant farmers have a rich international network, including close contacts in their home country as well as in Sweden, which gives possibilities for collaboration. These different kinds of cooperation make farming less vulnerable to fluctuations in weather and prices. Moreover, it gives opportunities for investments that might not have been possible for an individual farmer. Altogether, these strategies compensate for the lack of family support in Sweden that these immigrant farmers face.

This study adds to earlier research by showing the complexity of the challenges facing young immigrant farmers. It is not just price falls and the weather that can spell potential disaster for the farming business. A worst case scenario could be that the farmer's relationship crashes, or that the untenable workload leads to health problems that eventually put an end to the ability to work. This vulnerability seems to be more pronounced for immigrant farmers compared to family farmers since they lack key resources as farm specific and local knowledge as well as parents helping out. Our study acknowledges Sexmiths's (2019) findings from the US where dairy farmers express modern aspirations to have vacations and to work less to be able to have a functional social life. In addition, we show how challenges are connected since the young farmers see economic problems as the worst threat to relationships. It is alarming that the workloads for these young immigrant farmers are so heavy that it seems impossible to continue in the same way in the long run. They are aware that this could lead to problems with handling the business and, in the worst cases, accidents caused by fatigue.

Our results confirm EU policy reports (EP 2015, 2017) that highlight the need for knowledge and support adapted to young farmers' specific situations, and research that points at the challenging social and psychological situation (May et al., 2019). This study suggests that even though new entrants, and in this case, immigrant farmers, find ways to get access to different forms of capital, they need special attention when it comes to local knowledge and support. One way of doing that is through mentoring programs or extended advisory and support service which could make it possible to take vacation. Another way of facilitating knowledge and learning exchange is to arrange field visits where farmers can meet at a farm and discuss different solutions. Moreover, our study indicates that it is important to support farmers' networks in a time when there is an increasing distance between the farms. Looking in a EU perspective, this is especially important in more sparsely populated countries like Sweden. In our study, social media seems to be a source for networking and knowledge advice, and for young immigrant, farmers' digital platforms may be very important places for learning.

In this article, we wondered how young immigrant farmers, seemingly lacking all sorts of capital that we usually assume come for free to family farm successors, still manage to establish a farm. Elsewhere, we have argued that even in non-farm succession, good relationships between the former farmer and the new farmer can arise (Joosse and Grubbström, 2017). In such a case, the new farmer is often able to gain some of the capital, in terms of local networks, labour support etc. However, this depends much on how the new and the former farmer get along. But this is not the only way that young immigrant farmers can get access to different forms of capital, or compensate for capital that they are missing. In this paper, we show a variety of strategies that young immigrant farmers employ to this end. While the farmers we met and spoke with were very motivated and well capable to establish and maintain a farm, there are some uphill fights that take much energy. We have proposed some policy efforts that could help make this process a bit smoother. We hope this article can help formulate and target such efforts. 


\section{Acknowledgements}

This research would not have been possible without the generous help of the young farmers that we met. Ann Grubbström also wishes to thank the Carl-Fredrik von Horn Foundation, administered by The Royal Swedish Academy of Agriculture and Forestry (KSLA), for financial support of this research. Grubbström and Joosse have also used empirical material from the project: Looking for farmers. Young farmers' future strategies in a transforming sector funded by The Swedish Farmers' Foundation for Agricultural Research (SLF).

\section{Academic references}

[1] Ashkenazy, A., Chebach, T. C., Knickel, K., Peter, S., Horowitz, B. \& Offenbach, R. (2018). Operationalising resilience in farms and rural regions-findings from fourteen case studies. Journal of Rural Studies, 59, 211-221. DOI: 10.1016/j.jurstud.2017.07.008.

[2] Borisov, P., Radev, T. \& Nikolov, D. (2019). Young farmers and new entrants in Bulgarian agriculture-profiling their challenges and needs. Ikonomika $i$ upravlenie na selskoto stopanstvo/Bulgarian Journal of Agricultural Economics and Management, 64(2), 60-71.

[3] Bourdieu, P. (1986). The forms of capital. In: Richardson, G. G., ed., Handbook of Theory and Research for the Sociology of Education (pp. 241-258). Westport, CT: Greenwood.

[4] Bourdieu, P. \& Wacquant, L. J. D. (1992). An invitation to reflexive sociology. Cambridge. UK: Polity Press.

[5] Burton, R. J. \& Fischer, H. (2015). The Succession Crisis in European Agriculture. Sociologia Ruralis, 55(2), 155-166. DOI: 10.1111/soru.12080.

[6] Carolan, M. (2018). Lands changing hands: Experiences of succession and farm (knowledge) acquisition among first-generation, multigenerational, and aspiring farmers. Land Use Policy, 79, 179-189. DOI: 10.1016/j.landusepol.2018.08.011.

[7] Darnhofer, I., Lamine, C., Strauss, A. \& Navarrete, M. (2016). The resilience of family farms: Towards a relational approach. Journal of Rural Studies, 44, 111-122. DOI: 10.1016/j.jrurstud.2016.01.013.

[8] Davidova, S. \& Thomson, K. (2014). Family farming in Europe: Challenges and prospects. In-depth analysis. Brussel: European Parliament. DOI: 10.2861/55145.

[9] Eimermann, M. (2015). Lifestyle migration to the North: Dutch families and the decision to move to rural Sweden. Population, Space and Place, 21(1), 68-85. DOI: 10.1002/psp.1807.

[10] Eistrup, M., Sanches, A. R., Muñoz-Rojas, J. \& Pinto Correia, T. (2019). A "Young Farmer Problem"? Opportunities and Constraints for Generational Renewal in Farm Management: An Example from Southern Europe. Land, 8(4), 70. DOI: 10.3390/land8040070.

[11] Errington, A. \& Lobley, M. (2002). Handing over the reins. A comparative study of international farm transfers. In Agricultural Economics Society Annual Conference. Wageningen: European Association of Agricultural Economists. DOI: 10.22004/ag.econ.24905.

[12] Grubbström, A. \& Eriksson, C. (2018). Retired Farmers and New Land Users: How Relations to Land and People Influence Farmers' Land Transfer Decisions. Sociologia Ruralis, 58(4), 707-725. DOI: 10.1111/soru.12209.

[13] Hamilton, W., Bosworth, G. \& Ruto, E. (2015). Entrepreneurial younger farmers and the "young farmer problem" in England. Agriculture and Forestry, 61(4), 61-69. DOI: 10.17707/AgricultForest.61.4.05.

[14] Herman, A., Lähdesmäki, M. \& Siltaoja, M. (2018). Placing resilience in context: investigating the changing experiences of Finnish organic farmers. Journal of Rural Studies, 58, 112-122. DOI: 10.1016/j.jrurstud.2017.12.029. 
[15] Inwood, S. M. \& Sharp, J. S. (2012). Farm persistence and adaptation at the rural-urban interface: Succession and farm adjustment. Journal of Rural Studies, 28(1), 107-117. DOI: 10.1016/j.jrurstud.2011.07.005.

[16] Joosse, S. \& Grubbström, A. (2017). Continuity in farming - not just family business. Journal of Rural Studies, 50, 198-208. DOI: 10.1016/j.jrurstud.2016.11.018.

[17] Kauffman, N. S. (2013). Credit markets and land ownership for young and beginning farmers. Choices, 28 (2), 1-5.

[18] Kennedy, L. (1991). Farm succession in modern Ireland: elements of a theory of inheritance. Economic History Review 44(3), 477-499. DOI: 10.2307/2597540.

[19] Koutsou, S., Partalidou, M. \& Ragkos, A. (2014). Young farmers' social capital in Greece: Trust levels and collective actions. Journal of Rural Studies, 34, 204-211. DOI: 10.1016/j.jrurstud.2014.02.002.

[20] Lobley, M. (2010). Succession in the family farm business. Journal of Farm Management, 13(12). 839-851.

[21] Maclean, K., Cuthill, M. \& Ross, H. (2014). Six attributes of social resilience. Journal of Environmental Planning and Management, 57(1), 144-156. DOI: 10.1080/09640568.2013.763774.

[22] Mailfert, K. (2007). New farmers and networks: how beginning farmers build social connections in France. Tijdschrift voor economische en sociale geografie, 98(1), 21-31. DOI: 10.1111/j.1467-9663.2007.00373.x.

[23] May, D., Arancibia, S., Behrendt, K. \& Adams, J. (2019). Preventing young farmers from leaving the farm: Investigating the effectiveness of the young farmer payment using a behavioural approach. Land Use Policy, 82, 317-327. DOI: 10.1016/j.landusepol.2018.12.019.

[24] Meuleners, A. (2013). Finding fields: opportunities to facilitate and incentivize the transfer of agricultural property to new and beginning farmers. Drake Journal of Agricultural Law, 18, 211-238.

[25] Ngo, M. \& Brklacich, M. (2014). New farmers' efforts to create a sense of place in rural communities: insights from southern Ontario, Canada. Agriculture and Human Values, 31(1), 53-67. DOI: 10.1007/s10460-013-9447-5.

[26] Pérez, R. D. G., Sendra, M. J. M. \& López-i-Gelats, F. (2020). Strategies and drivers determining the incorporation of young farmers into the livestock sector. Journal of Rural Studies, 78, 131-148. DOI: 10.1016/j.jrurstud.2020.06.028.

[27] Sexsmith, K. (2019). Decoding Worker "Reliability": Modern Agrarian Values and Immigrant Labor on New York Dairy Farms. Rural Sociology 84(4), 706-735. DOI: 10.1111/ruso.12267.

[28] Siisiainen, M. (2003). Two concepts of social capital: Bourdieu vs. Putnam. International Journal of Contemporary Sociology, 40(2), 183-204.

[29] Sloot, P., de Lauwere, C., Zondag, M. \& Pauer, A. (2016). Needs of young farmers. Brussel: European Commission. DOI: 10.2762/13075.

[30] Šūmane, S., Kunda, I., Knickel, K., Strauss, A., Tisenkopfs, T., des los Rios, I., Rivera, M., Chebach, T. \& Ashkenazy, A. (2018). Local and farmers' knowledge matters! How integrating informal and formal knowledge enhances sustainable and resilient agriculture. Journal of Rural Studies, 59, 232-241. DOI: 10.1016/j.jrurstud.2017.01.020.

[31] Sutherland, L. A. \& Burton, R. J. (2011). Good farmers, good neighbours? The role of cultural capital in social capital development in a Scottish farming community. Sociologia Ruralis, 51(3), 238-255. DOI: 10.1111/j.1467-9523.2011.00536.x. 
[32] Valliant, J. C., Ruhf, K. Z., Gibson, K. D., Brooks, J. R. \& Farmer, J. R. (2019). Fostering farm transfers from farm owners to unrelated, new farmers: A qualitative assessment of farm link services. Land Use Policy, 86, 438-447. DOI: 10.1016/j.landusepol.2019.05.004.

[33] Woods, M. (2014). Family farming in the global countryside. Anthropological Notebooks, 20(3), 31-48.

[34] Zagata, L., Hrabák, J., Lošták, M., Bavorová, M., Ratinger, T., Sutherland, L.-A. \& McKee, A. (2017). Research for AGRI Committee - Young farmers - Policy implementation after the 2013 CAP reform. Brussel: European Parliament. DOI: 10.2861/536526.

[35] Zagata, L. \& Sutherland, L. A. (2015). Deconstructing the 'young farmer problem in Europe': Towards a research agenda. Journal of Rural Studies, 38, 39-51. DOI: 10.1016/j.jrurstud.2015.01.003.

Other sources

[36] EU (2016). Agriculture Statistics - Family Farming in the EU. Accessed online: 2020-11-02. Available online: https://ec.europa.eu/eurostat/statisticsexplained/index.php/Agriculture_statistics_-_family_farming_in_the_EU

[37] Swedish board of Agriculture (2007). Svenska och utländska nystartare av mjölkproduktion i Sverige - intervjuundersökning. Rapport 2007:17.

[38] Swedish board of agriculture (2014). Entrepreneurs and employed with foreign background in the Swedish agricultural sector. Statistik från Jordbruksverket. Statistikrapport 2014:01.

[39] Swedish board of agriculture (2017). Basic facts on Agriculture. http://www.jordbruksverket.se/omjordbruksverket/statistik/statistikomr/jordbruksstatistisksa mmanstallning/basfaktaomsvensktjordbruk.4.116e9b9d159b31e6cb936b4a.html.

[40] Swedish board of agriculture (2018). Agricultural statistic compilation, 2018:37 and 2018:107.

https://www.scb.se/contentassets/0a1612046e24433ebbdcea80aceb8ae0/jo1901_2017a0 1_br_jo02br1801.pdf Accessed online 2020-11-27.

[41] Swedish board of agriculture (2019). Price on agricultural land 2019. https://jordbruksverket.se/om-jordbruksverket/jordbruksverkets-officiellastatistik/jordbruksverkets-statistikrapporter/statistik/2020-08-27-priser-pa-jordbruksmark2019\#: :text=\%C3\%85r\%202019\%20var\%20det\%20genomsnittliga,betesmark\%20minska de\%20med\%20drygt\%203\%20\%25. Accessed on line 2020-11-21. 